\title{
Synthesis and Biological Activity of $\mathrm{N}^{0}$-( $p$-Sulfophenyl)alkyl and No-Sulfoalkyl Derivatives of Adenosine: Water-Soluble and Peripherally Selective Adenosine Agonists
}

\author{
Kenneth A. Jacobson ${ }^{\star}, \dagger$, Olga Nikodijevic ${ }^{\dagger}, \mathrm{Xiao}^{-d u o} \mathrm{Ji}^{\dagger}$, Deborah A. Berkich ${ }^{\ddagger}$, David \\ Eveleth$^{\S}$, Reginald L. Dean ${ }^{\S}$, Ken-Ichiro Hiramatsull, Neal F. Kasselll, Philip J. M. van \\ Galen $^{\dagger}$, Kevin S. Leell, Raymond T. Bartus ${ }^{\S}$, John W. Daly ${ }^{\dagger}$, Kathryn F. LaNoue ${ }^{\ddagger}$, and Michel \\ Maillard ${ }^{\dagger}$ \\ Laboratory of Bioorganic Chemistry, National Institute of Diabetes, Digestive and Kidney \\ Diseases, National Institutes of Health, Bethesda, Maryland 20892, Hershey Medical Center, \\ Pennsylvania State University, Hershey, Pennsylvania 17033, Cortex Pharmaceuticals, Inc., \\ Irvine, California 92718, and Department of Neurosurgery, University of Virginia, Charlottesville, \\ Virginia 22908
}

\section{Abstract}

A series of $N^{6}$-( $p$-sulfophenyl)alkyl and $N^{6}$ sulfoalkyl derivatives of adenosine was synthesized, revealing that $N^{6}$-( $p$-sulfophenyl)adenosine (10b) is a moderately potent $\left(K_{\mathrm{i}}\right.$ vs $\left[{ }^{3} \mathrm{H}\right] \mathrm{PIA}$ in rat cortical membranes was $74 \mathrm{nM}$ ) and $\mathrm{A}_{1}$-selective (120-fold) adenosine agonist, of exceptional aqueous solubility of $>1.5 \mathrm{~g} / \mathrm{mL}(\approx 3 \mathrm{M})$. Compound $10 \mathrm{~b}$ was very potent in inhibiting synaptic potentials in gerbil hippocampal slices with an $\mathrm{IC}_{50}$ of $63 \mathrm{nM}$. At a dose of $0.1 \mathrm{mg} / \mathrm{kg}$ ip in rats, 10b inhibited lipolysis (a peripheral $A_{1}$ effect) by $85 \%$ after $1 \mathrm{~h}$. This in vivo effect was reversed using the peripherally selective $\mathrm{A}_{1}$-antagonist 1,3-dipropyl-8-[ $p$-(carboxyethynyl)phenyl]xanthine (BW1433). The same dose of 10b in NIH Swiss mice (ip) was nearly inactive in locomotor depression, an effect that has been shown to be centrally mediated when elicited by lower doses of other potent adenosine agonists, such as $N^{6}$-cyclohexyladenosine (CHA) (Nikodijevic et al. FEBS Lett. 1990, 261, 67). HPLC studies of biodistribution of a closely related and less potent homologue, $N^{6}$-[4-( $p$-sulfophenyl)butyl]adenosine indicated that a $25 \mathrm{mg} / \mathrm{kg}$ ip dose in mice resulted in a plasma concentration after $30 \mathrm{~min}$ of $0.46 \mu \mathrm{g} / \mathrm{mL}$ and no detectable drug in the brain (detection limit $<0.1 \%$ of plasma level). Although $10 \mathrm{~b}$ at doses $>0.1 \mathrm{mg} / \mathrm{kg}$ in mice depressed locomotor activity, this depression was unlike the effects of CHA and was reversible by BW1433. These data suggest that $\mathbf{1 0 b}$ is a potent adenosine agonist in vivo and shows poor CNS penetration.

\section{Introduction}

Adenosine agonists, such as $N^{6}$-cyclohexyladenosine (CHA), cause intense behavioral effects at low doses. ${ }^{1-4}$ The locomotor depression elicited by peripherally administered $\mathrm{N}^{6}$ substituted adenosine analogs is usually interpreted as a central nervous system (CNS) effect. Evidence for central mediation of the depressant effect is that very low agonist doses administered directly into the brain are effective ${ }^{5}$ and that peripherally selective antagonists,

\footnotetext{
*Address correspondence to Dr. Kenneth A. Jacobson, Bldg. 8A, Rm. B1A-17, NIDDK/NIH, Bethesda, MD 20892. Tel. (301) 496-9024. FAX (301) 402-0008.

†National Institute of Diabetes, Digestive and Kidney Diseases.

${ }^{\ddagger}$ Pennsylvania State University.

$\$$ Cortex Pharmaceuticals, Inc.

University of Virginia.
} 
such as ( $p$-sulfophenyl)xanthine derivatives, ${ }^{2,6,7}$ are inactive in reversing this depression. The nonselective xanthines, caffeine and theophylline, which freely cross the blood-brain barrier, reverse adenosine-agonist-induced behavioral depression.

It has been shown that adenosine $\mathrm{A}_{1}$ agonists protect against ischemia-induced brain degeneration, ${ }^{8,9}$ possibly by modulating excitatory amino acid toxicity in the CNS. However, the multiple actions of adenosine, ${ }^{10,11}$ including both peripherally and/or centrally-mediated effects, complicate interpretation of these results.

As tools to aid in delineating central and peripheral adenosine agonist effects, we have synthesized a series of sulfonates related to $N^{6}$-(phenylalkyl) and $N^{6}$-alkyl derivatives of adenosine that are known potent agonists. The sulfonate group is completely charged at physiological $\mathrm{pH}$ and is expected to preclude passage of the derivative across the blood brain barrier, by analogy with ( $p$-sulfophenyl)-theophylline and its analogues. ${ }^{6}$

\section{Chemistry}

The sulfoamine derivatives $\mathbf{3 b}$ and $\mathbf{6 b}-\mathbf{c}$ were prepared according to the routes shown in Figure 1. For $\mathbf{3 b}$, monosulfonation of the dibromoalkane 1 was followed by amination. Compounds $6 \mathbf{b}$ and $6 \mathrm{c}$ were obtained by amination of 4 and sulfonation of 5 , respectively. Reaction of 6-chloropurine riboside, 7, with the appropriate sulfonated amine provided compounds 8b-12b (Figure 2).

The sulfonate derivatives were considerably more hydrophilic than the corresponding hydrogen analogs. Compound 11b could be dissolved in neutral phosphate buffer (100 mM) at a concentration of $0.8 \mathrm{M}$. In comparison, a carboxylic acid derivative prepared in a previous study, ${ }^{13} N^{6}$-[ $p$-(carboxymethyl)phenyl] adenosine, had a maximum aqueous solubility of $2.1 \mathrm{mM}$. Compound $\mathbf{1 0 b}$ was especially soluble, with an aqueous solubility of > $1.5 \mathrm{~g} / \mathrm{mL}(\approx 3 \mathrm{M})$.

\section{Biological Evaluation}

\section{Binding Assay}

The analogs were tested in a radioligand binding assay for affinity at adenosine receptors in rat brain membranes. The compounds were assayed for affinity at rat $\mathrm{A}_{1}$ cortical receptors using $\left[{ }^{3} \mathrm{H}\right]-N^{6}$-(phenylisopropyl)adenosine ${ }^{17}$ and at rat $\mathrm{A}_{2}$ striatal receptors using $\left[{ }^{3} \mathrm{H}\right] \mathrm{CGS}$ 21680 (Table I). ${ }^{12}$ The (sulfoalkyl)-adenosine derivative $\mathbf{8 b}$ was essentially inactive in binding to both $\mathrm{A}_{1}$ and $\mathrm{A}_{2}$ adenosine receptors. Compound $\mathbf{9 b}$ was comparable in potency and selectivity to the longer chain [(sulfophenyl)alkyl]adenosine derivatives. The $K_{\mathrm{i}}$ values for the [(sulfophenyl)alkyl]adenosine derivatives 10b-12b ranged from 74 to $610 \mathrm{nM}$ at $\mathrm{A}_{1}$ receptors. The orders of both potency and selectivity at $A_{1}$ receptors were 10b $>\mathbf{1 2 b}>\mathbf{1 1 b}$. The highest degree of $A_{1}$ selectivity, 120-fold, was observed for compound 10b. Compound $\mathbf{1 1 b}$ was only slightly $A_{1}$ selective. Except for $\mathbf{8 b}$, the effect of adding a sulfonate group to an $N^{6}$-adenosine derivative was to diminish the $\mathrm{A}_{1}$-receptor affinity by $20-60$-fold. At $\mathrm{A}_{2}$ receptors, the differences in affinity between the sulfo and corresponding $\mathrm{H}$ analogues was less pronounced. Curiously, the very low affinity of $N^{6}$-decyladenosine, 9a, at $A_{2}$ receptors was enhanced 7-fold in the corresponding terminal sulfo derivative, $\mathbf{9 b}$.

\section{Brain versus Plasma Concentrations}

For HPLC studies of biodistribution of the sulfonated adenosine derivatives, a weakly potent derivative [ ${ }^{6}$-4-( $p$-sulfophenyl)butyl] adenosine, 12b) was chosen to allow larger doses to be injected for detection purposes. Thus, a relatively high plasma concentration could be achieved without complicating or detrimental biological effects. A $25 \mathrm{mg} / \mathrm{kg}$ ip dose of $\mathbf{1 2 b}$ 
in mice resulted in a plasma concentration of $0.46 \mu \mathrm{g} / \mathrm{mL}$ after $30 \mathrm{~min}$ and no detectable drug in the brain (detection limit $<0.1 \%$ of plasma level). At this dose moderate locomotor depression of the mice was observed.

\section{Electrophysiology}

Adenosine derivatives are potent inhibitors of synaptic potentials in the hippocampal formation, an action mediated by $\mathrm{A}_{1}$ receptors. ${ }^{18}$ Several sulfonate derivatives and reference ligands were characterized for the ability to inhibit synaptic transmission using in vitro rat or gerbil hippocampal slices (Table II). Synaptic responses (field excitatory postsynaptic potential (fEPSPs)) were recorded in the CA1 region. All of the adenosine derivatives inhibited fEPSPs in a dose-dependent manner. The order of potency corresponded more roughly to affinity at $\mathrm{A}_{1}$ receptors. CGS 21680 , an $\mathrm{A}_{2}$-selective agonist, was of very low potency. Compound $10 \mathrm{~b}$ was very potent in inhibiting synaptic potentials in both rat and gerbil hippocampal slices with $\mathrm{IC}_{50}$ values of 74 and $63 \mathrm{nM}$, respectively, comparable in potency to $R$-PIA. Characteristic of $R$-PIA and other potent adenosine $\mathrm{N}^{6}$ derivatives, such as CHA ( $N^{6}$-cyclohexyladenosine) and ADAC ( $N^{6}$-[4-[[[4-[[[(2-aminoethyl)amino]carbonyl]methyl]anilino]carbonyl]methyl]phenyl]-adenosine), is a slow onset of action and a slow washout. The onset of action of $\mathbf{1 0 b}$ was comparable to that of adenosine itself (very rapid), and the washout was also rapid. The $\mathrm{A}_{1}$-selective adenosine antagonist CPX (8cyclopentyl-1,3-dipropylxanthine) blocked the inhibitory effects of this derivative (gerbil). The propyl derivative 11b was found to be approximately as potent as 2-chloroadenosine (2$\mathrm{CADO})$ in this assay with an $\mathrm{IC}_{50}$ value of $1.7 \mu \mathrm{M}$. Thus, this sulfonate derivative clearly acted as an agonist, in spite of its relatively low affinity at $\mathrm{A}_{1}$ receptors $\left(K_{\mathrm{i}} 610 \mathrm{nM}\right)$. This derivative had a slightly slower onset of action in this assay than adenosine itself, but a faster onset of action than $N^{6}$-cyclopentyladenosine (CPA). The dose-response curves show that this sulfonate derivative is more potent than adenosine, yet considerably less potent than CPA.

\section{In Vivo Lipolysis}

Adenosine agonists cause inhibition of lipolysis via activation of $\mathrm{A}_{1}$ receptors in isolated adipocytes and likewise result in a lowering of serum glycerol levels in vivo. ${ }^{29}$ Three (sulfophenyl)alkyl adenosine derivatives (10b-12b) were examined as inhibitors of lipolysis in vivo in rats at doses of $0.1-1.0 \mathrm{mg} / \mathrm{kg}$ and were found to lower serum glycerol levels. The maximum effect was seen at 30-60 min post subcutaneous injection (Figure 3). The (sulfophenyl)propyl derivative 11b lowered the serum glycerol levels in rats at $60 \mathrm{~min}$ following injection by $30 \%$ and $34 \%$ at doses of 0.5 and $1.0 \mathrm{mg} / \mathrm{kg}$, respectively (data not shown). Compound $\mathbf{1 0 b}$ was considerably more potent in the inhibition of lipolysis, with a dose of $0.1 \mathrm{mg} / \mathrm{kg}$ nearly completely suppressing serum glycerol levels. Compound $\mathbf{1 2 b}$ was the weakest of the three derivatives in the lipolysis assay. The antilipolytic effects elicited by adenosines agonists $\mathbf{1 0 b}-\mathbf{1 2 b}$ (Figure 3 ) were fully or nearly completely antagonized by the peripherally selective adenosine antagonist BW1433 (1,3-dipropyl-8-[ $p$ (carboxyethynyl)phenyl]xanthine) ${ }^{23}$ at a dose of $4 \mathrm{mg} / \mathrm{kg}$, administered simultaneously. BW1433 alone raised serum glycerol levels by a small amount, from $296 \pm 20 \mu \mathrm{M}$ before injection to $326 \pm 15 \mu \mathrm{M}$ at 60 min postinjection.

\section{Locomotor Activity}

Adenosine agonists are potent locomotor depressants, ${ }^{1-3}$ and the onset of the effect is generally rapid. Several derivatives were examined in a behavioral assay, using a computerized animal activity monitor cage. The locomotor activity of mice, control and drug-treated, was followed over a 90-min time course, with measurements made in 10-min intervals (Figure 4A). A $0.1 \mathrm{mg} / \mathrm{kg}$ dose of $\mathbf{1 0 b}$ administered to NIH Swiss mice (ip) was 
only weakly active in locomotor depression (total distance traveled during 60 min was $82 \pm$ $11 \%$ of vehicle control, $n=6$ ). Doses of 0.3 and $1.0 \mathrm{mg} / \mathrm{kg}$ in mice produced locomotor activity over $60 \mathrm{~min}$ of $73 \pm 7.8 \%(n=20)$ and $11.6 \pm 2.6 \%(n=7)$ of control, respectively. This depression was quantitatively and qualitatively unlike the effects of $N^{6}$ cyclohexyladenosine, for which the $\mathrm{EC}_{50}$ dose was found to be much lower $(\sim 0.1 \mathrm{mg} / \mathrm{kg})$. At the higher doses of $\mathbf{1 0 b}$, the animals did not respond to touch, there was no analgesia, and body posture was different from that of CHA. CHA-depressed animals respond to touch and exhibit a diminished response to painful stimulus, such as pressure applied to the tail. Over a period of $1 \mathrm{~h}$, mice injected with $0.3 \mathrm{mg} / \mathrm{kg} 10 \mathrm{~b}$ traveled $3900 \pm 400 \mathrm{~cm} / 60 \mathrm{~min}$ (total distance, $n=20)$ compared to control animals traveling $5300 \pm 300 \mathrm{~cm} / 60 \mathrm{~min}(n=25)$. The depression elicited by a dose of $0.3 \mathrm{mg} / \mathrm{kg} 10 \mathrm{~b}$ was completely reversed (over a 30-min period) by a $0.25 \mathrm{mg} / \mathrm{kg}$ ip dose of CPX. The depression elicited by $0.3 \mathrm{mg} / \mathrm{kg} 10 \mathrm{~b}$ was also reversed by a $4 \mathrm{mg} / \mathrm{kg}$ dose of BW1433 (Figure 4B). Mice receiving a combination of 10b and BW1433 traveled $5150 \pm 700 \mathrm{~cm} / 60 \mathrm{~min}(n=12)$. BW1433 alone resulted in $5650 \pm$ $700 \mathrm{~cm} / 60 \mathrm{~min}$ traveled $(n=10)$. The butyl derivative, $\mathbf{1 2} \mathbf{b}$, was shown to be inactive as a locomotor depressant in mice at a dose of $1 \mathrm{mg} / \mathrm{kg}$ (data not shown). However, at a $5 \mathrm{mg} / \mathrm{kg}$ dose of $\mathbf{1 2 b}$ pronounced locomotor depression was observed, and this effect disappeared after $60 \mathrm{~min}$ postinjection. Very high doses of the propyl derivative $11 \mathbf{b}(25$ and $50 \mathrm{mg} / \mathrm{kg}$ ip) also produced moderate locomotor depression in rats during $1 \mathrm{~h}$.

Unlike the depression elicited by $\mathbf{1 0 b}$, the locomotor depression elicited by CHA was not reversed by BW1433, consistent with the primary central mode of action of CHA at this dose. Over a 30-min period, CHA alone (100 $\mu \mathrm{g} / \mathrm{kg}$, ip) produced locomotor activity of $64 \pm$ $12 \%(n=7)$ of control. CHA in combination with a $4 \mathrm{mg} / \mathrm{kg}$ dose of BW1433 elicited locomotor activity of $73 \pm 6.4 \%(n=10)$, relative to BW1433 alone.

\section{Body Temperature}

Either parenteral (ip) or central (icv) administration of the (sulfophenyl)propyl derivative, 11b, caused rectal temperature depression in rats (Figure 5). In comparison, vehicle administered by the same routes caused a small rise in temperature (by approximately $1{ }^{\circ} \mathrm{C}$ ). Thus, it appears that there are multiple components (both peripheral and central) to temperature depression by adenosine agonists. This observation is consistent with previous reports on hypothermic effects of adenosine analogues. ${ }^{10,21,22}$

\section{Discussion}

Adenosine agonists have been proposed to be cerebro-protective agents. ${ }^{8}{ }^{8} \mathrm{CHA}$, a potent $\mathrm{A}_{1}$-selective agonist had a protective effect on the ischemic brains in gerbils and rats, as judged from both histological evidence ${ }^{8,9}$ and survival rates. ${ }^{9}$ A proposed mechanism for this phenomenon is interference with the glutamic acid pathways, either presynaptically to inhibit the release of glutamic acid or postsynaptically to interfere with its "excitotoxic" effect through reduction of calcium influx.

It was suggested that other effects of adenosine, such as temperature depression, cardiovascular depression, or CNS depression, may complicate interpretation of the phenomenon of cerebroprotection. Hypothermia alone has been demonstrated to be neuroprotective in the rat model. ${ }^{23}$

In general, there is uncertainty about the central vs peripheral nature of some of the physiological effects of adenosine. For example, temperature regulation by adenosine receptor ligands appears to have both central and peripheral components. ${ }^{10,21,22}$ Even the question of whether some of the more potent adenosine agonists such as $R$-PIA enter the CNS altogether when administered peripherally has been subject to debate. ${ }^{24}$ 
We have synthesized a series of charged derivatives of adenosine as putative peripheral agonists. These sulfonate derivatives may prove useful in determining if the cerebroprotective effect of adenosine agonists and other adenosine effects are due to the central and/or peripheral activation of adenosine receptors.

It was desirable to introduce a sulfonate group, which would be permanently charged at physiological $\mathrm{pH}$, on an $\mathrm{N}^{6}$-substituent, the position of greatest flexibility of substitution among $\mathrm{A}_{1}$-selective analogs. However, negatively charged groups at the $\mathrm{N}^{6}$-position are known to diminish affinity at adenosine receptors. ${ }^{13}$ Several carboxylate-bearing derivatives have been reported to have affinities roughly two orders of magnitude less than the corresponding hydrogen-bearing derivatives. For example, $N^{6}$-[ $p$-(carboxymethyl)phenyl] adenosine and $N^{6}$ - $p$-tolyladenosine have $K_{\mathrm{i}}$ values at $\mathrm{A}_{1}$ receptors of 210 and $2.5 \mathrm{nM}$, respectively. ${ }^{13}$ Likewise, in the case of xanthines acting as adenosine antagonists, the presence of anionic groups on 8-phenyl substituents leads to diminished affinity. ${ }^{25}$ Nevertheless, $p$-(sulfophenyl)theophylline has found wide use, ${ }^{2,9,26}$ and its lower potency is acceptable due to its selective biodisposition and favorable aqueous solubility. Both 8-SPT (8-(p-sulfophenyl)theophylline) and the more potent carboxylate xanthine derivative BW $1433^{20}$ appear to be peripherally-selective adenosine antagonists. BW1433 is inactive in reversing the CNS-mediated effects of adenosine agonists in previous studies (S. Daluge, unpublished results) and in this study. BW1433 administered ip in rats as the sodium salt (30 $\mathrm{mg} / \mathrm{kg}$, suspension in $0.5 \%$ methylcellulose) has a half-life of $2.4 \mathrm{~h}$ (P. Savina and R. Blum, unpublished results). Similarly, the present agonist derivatives are considerably less potent in binding assays than the analogous uncharged derivatives (Table I). It appears that a sulfonate group diminishes affinity independent of the size of the $\mathrm{N}^{6}$-substituent, suggesting an unfavorable interaction with negatively charged membrane components, e.g. lipids. The lower potency of some of these sulfonated agonists may be tolerated for in vivo studies taking into consideration selective biodisposition, as indicated in the HPLC studies.

The hydrophilicity of the sulfoadenosine derivatives is consistent with the low $\mathrm{p} K_{\mathrm{a}}$ of an aryl sulfonic acid group (0-1) compared to that of a carboxylic acid (3-5) ${ }^{30}$ Thus, the proportion of the analog that exists in charged form at physiological $\mathrm{pH}$ would be much greater for a sulfonic acid than for a carboxylic acid. Also, the $\pi$-value of a sulfonate group $(-4.76)$ suggests a somewhat greater tendency to partition into an aqueous phase than the value for a carboxylate (-4.36). ${ }^{31}$ The $\log P$ value for $R$-PIA was reported to be $\sim 2.0 .{ }^{32}$ Applying the correlation analysis for changing substituents predicts a $\log P$ value of 0.7 for $N^{6}$-phenyladenosine. Thus, the sulfo derivatives $\mathbf{1 0 b}$ and $\mathbf{1 2 b}$ have predicted $\log P$ values of -4.1 and -2.1 , respectively. These negative $\log P$ values are consistent with the observed low brain penetration.

A primary neuromodulatory action of adenosine is to inhibit excitatory synaptic responses in the brain. In the hippocampus, this effect has been shown to be mediated by $\mathrm{A}_{1}$ receptors. ${ }^{18,27}$ Both $\mathbf{1 0 b}$ and the propyl derivative $\mathbf{1 1 b}$ applied directly to hippocampal slices were found to be more potent in an electrophysiological model than would be predicted from their potencies in a binding assay relative to other agonists. In fact, the $\mathrm{IC}_{50}$ for inhibition of fEPSPs by $\mathbf{1 0 b}$ was identical to its $K_{\mathrm{i}}$ value at $\mathrm{A}_{1}$ receptors (Table II). The effects of the sulfo adenosine analogues and of adenosine itself are qualitatively different from those of CHA, ADAC, and other $\mathrm{N}^{6}$ derivatives ${ }^{16,18}$ in rapidity of onset and washout. The relatively high activity in the hippocampal slice assay might relate to its lack of diffusion into fatty structures or not being taken up into cells; thus it is fully available in the medium to activate $A_{1}$ receptors. For instance, uptake is sufficient to alter the apparent potency of adenosine and its analogs in slices (for a discussion see ref 33). Thus, compound $10 \mathrm{~b}$ represents a unique type of adenosine agonist which exhibits both high in vivo potency and rapid reversibility. 
Locomotor depression by uncharged and relatively hydrophobic adenosine agonists such as CHA is centrally mediated. ${ }^{2-4}$ At a dose of $0.1 \mathrm{mg} / \mathrm{kg}$ (highly active in the inhibition of lipolysis in vivo) 10b was nearly inactive in locomotor depression, although higher doses depressed behavioral activity. Thus, at lower doses the action of $\mathbf{1 0 b}$ (e.g. inhibition of lipolysis) is purely peripheral. At higher doses $\mathbf{1 0 b}$ preferentially activates $\mathrm{A}_{1}$ receptors in the peripheral nervous system, as suggested by the reversibility of the locomotor effects by BW1433. The precise mechanism for locomotor depression at higher doses is yet unknown, but may relate to cardiac depression or vasodilatation. It is a result of activation of $\mathrm{A}_{1}$ receptors, since it is reversible by both BW1433 and the potent and highly $\mathrm{A}_{1}$-selective antagonist CPX, but the tissue location of the relevant receptors is undetermined.

In conclusion, $N^{6}$-( $p$-sulfophenyl)adenosine (10b) is a potent $A_{1}$ adenosine agonist in receptor binding, in inhibitory electrophysiological effects in hippocampal slices, and in inhibition of lipolysis in vivo. A close homologue, 12b, did not cross the blood-brain barrier, even at very high doses. Compound $\mathbf{1 0 b}$ is even more polar than $\mathbf{1 2 b}$, and thus is expected to be similarly excluded from the brain. 10b, 11b, and 12b depressed locomotor activity only at high doses, but this depression appeared to be related to the peripheral effects of adenosine. A peripherally selective $\mathrm{A}_{1}$ adenosine agonist might have utility in treating cardiac ischemia, ${ }^{28}$ without producing CNS side effects.

\section{Experimental Section}

\section{Chemistry}

New compounds were characterized (and resonances assigned) by 300-MHz proton nuclear magnetic resonance mass spectroscopy using a Varian GEMINI-300 FT-NMR spectrometer. Unless noted, chemical shifts are expressed as ppm downfield from tetramethylsilane. Synthetic intermediates were characterized by chemical-ionization mass spectrometry $\left(\mathrm{NH}_{3}\right)$ and adenosine derivatives by fast atom bombardment mass spectrometry (JEOL SX102). C, $\mathrm{H}, \mathrm{N}$, and $\mathrm{S}$ analyses were carried out by Atlantic Microlabs (Norcross, GA), and $\pm 0.4 \%$ was acceptable. 6-Chloropurine riboside, 7, taurine, 3a, and sulfanilic acid, 6a, were purchased from Aldrich (St. Louis, MO) and p-(3-chloropropyl)benzenesulfonate, 4, was obtained from Schweizerhall, Inc. (South Plainfield, NJ). $N^{6}$-Phenyladenosine and 2chloroadenosine were purchased from Research Biochemicals, Inc. (Natick, MA). Compounds 11a and 12a were the gift of Dr. Ray Olsson (University of South Florida, Tampa, FL). Compounds 11a and 12a were the gift of Dr. Ad IJzerman (Center for Biopharmaceutical Sciences, Leiden, The Netherlands). BW1433 was the gift of Dr. S. Daluge (Burroughs Wellcome Co., Research Triangle Park, NC). Analytical TLC plates and silica gel (230-400 mesh) were purchased from VWR (Bridgeport, NJ). Silica gel $100 \mathrm{C}_{18}$ reversed-phase was obtained from Fluka (Ronkonoma, NY).

Sodium 10-Aminodecanesulfonate (3b)—A mixture of sodium sulfite (1.4 g, 1.1 mmol), 1,10-dibromodecane (1) $(7.5 \mathrm{~mL}, 3.3 \mathrm{mmol}), 25 \mathrm{~mL}$ of ethanol, and $20 \mathrm{~mL}$ of water was refluxed for $6 \mathrm{~h}$. The upper phase (1,10-dibromodecane) was removed, and the lower aqueous phase was washed with chloroform three times. The aqueous phase was concentrated by rotary evaporation at $50{ }^{\circ} \mathrm{C}$. The solid residue was dissolved in $10 \mathrm{~mL}$ of a $25 \%$ solution of ammonium hydroxide and heated at $100{ }^{\circ} \mathrm{C}$ in a sealed container for $3 \mathrm{~h}$. Sodium 10-aminodecanesulfonate (3b) separated upon cooling as a white crystalline solid. This material was isolated by filtration and washed successively with cold water and ether. MS (FAB [pos]/glycerol matrix): $\mathrm{m} / 2238 \mathrm{MH}_{2}{ }^{+} .{ }^{1} \mathrm{H}$ NMR $\delta\left(\mathrm{D}_{2} \mathrm{O}\right): 1.3(\mathrm{~m}, 12 \mathrm{H}), 1.65(\mathrm{~m}$, $\left.4 \mathrm{H}, \mathrm{CH}_{2} \mathrm{CH}_{2}-\mathrm{NH}_{2}+\mathrm{CH}_{2} \mathrm{CH}_{2} \mathrm{SO}_{3}\right), 3.28$ and $3.29\left(2 \mathrm{t}, 4 \mathrm{H}, \mathrm{CH}_{2} \mathrm{NH}_{2}+\mathrm{CH}_{2}-\mathrm{SO}_{3}\right)$. 
Sodium $\boldsymbol{p}$-(3-Aminopropyl)benzenesulfonate (6b)- $p$-(3-Chloropropyl)

benzenesulfonate (4) $(6 \mathrm{~g}, 23.4 \mathrm{mmol})$ was dissolved in $28 \mathrm{~mL}$ of a $25 \%$ solution of ammonium hydroxide and heated at $100{ }^{\circ} \mathrm{C}$ in a closed vessel for $3 \mathrm{~h}$. Sodium $p$-(3aminopropyl)-benzenesulfonate (6b) separated upon cooling as a white crystalline solid. This material was isolated by filtration and washed successively with cold water and ether (3.65 g, 66\%). MS (FAB [neg]/glycerol matrix): $\mathrm{m} / z 214 \mathrm{M}^{-}$. ${ }^{1} \mathrm{H}$ NMR $\delta$ (DMSO- $d_{6}$ ): 1.85 $\left(\mathrm{m}, 2 \mathrm{H}, \mathrm{CH} 2 \mathrm{CH}_{2} \mathrm{C}_{6} \mathrm{H}_{3}\right), 2.65$ and $2.80\left(2 \mathrm{t}, 4 \mathrm{H}, \mathrm{CH}_{2} \mathrm{NH}_{2}+\mathrm{CH}_{2} \mathrm{C}_{6} \mathrm{H}_{3}\right), 7.15(\mathrm{~d}, 2 \mathrm{H}$, arom $)$, 7.50 (d, $2 \mathrm{H}$, arom).

p-(4-Aminobutyl)benzenesulfonic Acid (6c)—4-Phenyl-butylamine (5) (15 g, 0.1 mol) was added dropwise at $0{ }^{\circ} \mathrm{C}$ to a mixture of concentrated sulfuric acid $(26 \mathrm{~mL})$ and fuming sulfuric acid $(15 \mathrm{~mL})$. After stirring at room temperature for $1 \mathrm{~h}$, the mixture was refluxed for an additional hour. After cooling, the solution was then poured into $1 \mathrm{~L}$ of dioxane. The solid obtained was filtered, washed several times with dioxane, and dried (18 g,78\%). MS (FAB [pos]/glycerol matrix): $\mathrm{m} / z 230 \mathrm{MH}_{2}{ }^{+}$. Anal. $\mathrm{C}_{10} \mathrm{H}_{15} \mathrm{NO}_{3} \mathrm{~S}(\mathrm{C}, \mathrm{H}, \mathrm{N}, \mathrm{S})$.

$N^{6}$-[( $p$-Sulfophenyl)alkyl]-, $N^{6}$-( $\omega$-Sulfoalkyl)-,or $N^{6}$-( $p$-Sulfophenyl)adenosine, Triethylammonium, Ammonium, or Sodium Salts (General Procedure for $\mathbf{8 b}$ 12b)-6-Chloropurine riboside (7) $(1 \mathrm{~g}, 3.5 \mathrm{mmol})$ and the appropriate sulfoamine (4.2 mmol) were suspended in $40 \mathrm{~mL}$ of $n$-butyl alcohol, and a 3-fold excess of triethylamine $(1.6 \mathrm{~mL})$ was added. For preparation of compounds $9 \mathbf{b}$ and $\mathbf{1 1 b}$, the sodium salts of the sulfo amines $3 \mathrm{~b}$ and 4 were used. The mixture was heated at $120^{\circ} \mathrm{C}$ for $24 \mathrm{~h}$. The reaction mixture was concentrated to a syrup and after dilution with chloroform loaded onto a $15 \times$ $4.5 \mathrm{~cm}$ column of silica gel (flash type). It then was eluted with a gradient of methanol in ethyl acetate (20-50\%) to remove the traces of unreacted material, followed by a mixture of chloroform-methanol (7:3, by volume) to elute the product. For compound $\mathbf{1 2 b}, 10 \%$ concentrated $\mathrm{NH}_{4} \mathrm{OH}$ was included in the elution solvent, the ammonium salt of the sulfo adenosine derivative was obtained. For compounds $\mathbf{9 b}-\mathbf{1 2} \mathbf{b}$, the solid obtained after evaporation was crystallized from a mixture of water and ethanol (roughly 1:50, by volume) that was placed under an ether atmosphere overnight. Compound $\mathbf{8 b}$ was purified by lowpressure reversed-phase chromatography on $\mathrm{C} 18$ silica (eluant: water/methanol, 8:2, by volume). Yields ranged between $42 \%$ and $63 \%$. Analysis: $(\mathrm{C}, \mathrm{H}, \mathrm{N}, \mathrm{S})$ for $\mathbf{8 b}\left(+1.5 \mathrm{H}_{2} \mathrm{O}\right.$, $\mathrm{Et}_{3} \mathrm{~N}$ salt), 10b $\left(\mathrm{Et}_{3} \mathrm{~N}\right.$ salt), and $\mathbf{1 2 b}\left(+1 \mathrm{H}_{2} \mathrm{O}, \mathrm{NH}_{4}\right.$ salt $) ;(\mathrm{C}, \mathrm{H}, \mathrm{N})$ for $\mathbf{1 1 b}\left(+1.5 \mathrm{H}_{2} \mathrm{O}\right.$, sodium salt); $(\mathrm{C}, \mathrm{H})$ for $\mathbf{9 b}\left(+1.5 \mathrm{H}_{2} \mathrm{O}\right.$, sodium salt $), \mathrm{N}$ calcd 13.05 , found 12.33 . ${ }^{1} \mathrm{H}$ NMR for 10b $\delta$ (DMSO- $\left.d_{6}\right): 1.15\left(\mathrm{t}, 9 \mathrm{H}, \mathrm{CH}_{3} \mathrm{CH}_{2}\right), 3.10\left(\mathrm{~m}, 6 \mathrm{H}, \mathrm{CH}_{2} \mathrm{CH}_{3}\right), 3.60$ and $3.70(\mathrm{~m}, 2$ $\left.\mathrm{H}, 5^{\prime}-\mathrm{H}\right), 3.98\left(\mathrm{~m}, 1 \mathrm{H}, 4^{\prime}-\mathrm{H}\right), 4.18\left(\mathrm{~m}, 1 \mathrm{H}, 3^{\prime}-\mathrm{H}\right), 4.64\left(\mathrm{~m}, 1 \mathrm{H}, 2^{\prime}-\mathrm{H}\right), 5.20(\mathrm{~d}, 1 \mathrm{H}, \mathrm{OH})$, $5.26(1,1 \mathrm{H}, \mathrm{OH}), 5.50(\mathrm{~d}, 1 \mathrm{H}, \mathrm{OH}), 5.96\left(\mathrm{~d}, 1 \mathrm{H}, 1^{\prime}-\mathrm{H} J_{1^{\prime}, 2^{\prime}}=6.4 \mathrm{~Hz}\right), 7.55$ and $7.90(\mathrm{~d}, 4$ $\mathrm{H}$, arom), 8.40 and $8.55(\mathrm{~s}, 2 \mathrm{H}, 2-\mathrm{H}$ and $8-\mathrm{H}), 10.0(\mathrm{~s}, 1 \mathrm{H}, \mathrm{NH}) . \varepsilon_{305}$ for $\mathbf{1 0 b}$ in methanol $\left(\lambda_{\max }\right) 33$ 100. MS (FAB [neg]/glycerol matrix): $\mathrm{m} / \mathrm{z} 422 \mathrm{M}^{-}$. Mp for 10b: $155-165{ }^{\circ} \mathrm{C}$.

\section{Biological Methods}

Receptor Binding-Rat cerebral cortical membranes and striatal membranes were prepared ${ }^{12,13}$ and treated with adenosine deaminase $(0.5$ units $/ \mathrm{mL})$ for 20 min at $37^{\circ} \mathrm{C}$ prior to radioligand binding studies or incorporation studies. Solid samples of the adenosine derivatives were dissolved in DMSO and stored at $-20^{\circ} \mathrm{C}$. The stock solutions were diluted with DMSO to a concentration of $\$ 0.1 \mathrm{mM}$ prior to adding to the aqueous medium. The final concentration of DMSO in the assay medium was generally $\triangleleft \%$.

Inhibition of binding of $1 \mathrm{nM}\left[{ }^{3} \mathrm{H}\right]-N^{6}$-(phenylisopropyl)-adenosine (Dupont NEN, Boston, MA) to $A_{1}$ receptors in rat cerebral cortex membranes was measured as described. ${ }^{17}$

Membranes ( $100 \mu \mathrm{g}$ of protein, $5 \mathrm{mg}$ wet weight, per tube) were incubated for $1.5 \mathrm{~h}$ at 37

${ }^{\circ} \mathrm{C}$ in a total volume of $2 \mathrm{~mL}$ of $50 \mathrm{mM}$ Tris hydrochloride, at $\mathrm{pH}$ 7.4. Adenosine deaminase 
was present $(2 \mathrm{IU} / \mathrm{mL})$ during the incubation with radioligand. Bound and free radioligand were separated by addition of $4 \mathrm{~mL}$ of a buffer containing $50 \mathrm{mM}$ Tris- $\mathrm{HCl}$, at $\mathrm{pH} 7.4$ at 5 ${ }^{\circ} \mathrm{C}$ followed by vacuum filtration using a Brandel Cell Harvester (Brandel, Gaithersburg, MD) and a Whatman GF/B glass fiber filter with additional washes totaling $12 \mathrm{~mL}$ of buffer. Nonspecific binding was determined with $10 \mu \mathrm{M}$ 2-chloroadenosine.

Inhibition of binding of $5 \mathrm{nM}\left[{ }^{3} \mathrm{H}\right] \mathrm{CGS} 21680$ [4-[2-[[6-amino-9-( $N$-ethyl- $\beta$-Dribofuranuronamidosyl)- $9 H$-purin-2-y]amino]-ethyl] benzenepropanoic acid] was carried out as described ${ }^{12}$ using $20 \mu \mathrm{M} 2$-chloroadenosine to determine nonspecific binding. Membranes ( $\sim 80 \mu \mathrm{g}$ of protein, $5 \mathrm{mg}$ wet weight, per tube) were incubated for $1 \mathrm{~h}$ at $25^{\circ} \mathrm{C}$ in a total volume of $1 \mathrm{~mL}$. Adenosine deaminase was present $(3 \mathrm{IU} / \mathrm{mL})$ during the incubation with radioligand. Filtration was carried out using a Brandel Cell Harvester, as above.

At least seven different concentrations spanning 4 orders of magnitude, adjusted appropriately for the $\mathrm{IC}_{50}$ of each compound, were used. $\mathrm{IC}_{50}$ values, computer-generated using a nonlinear regression formula on the GraphPAD program (Institute for Scientific Information), were converted to apparent $K_{\mathrm{i}}$ values using $K_{\mathrm{D}}$ values $^{12,13}$ of 1.0 and $14 \mathrm{nM}$ for $\left[{ }^{3} \mathrm{H}\right] \mathrm{PIA}$ and $\left[{ }^{3} \mathrm{H}\right] \mathrm{CGS} 21680$ binding, respectively, and the Cheng-Prusoff equation. ${ }^{14}$

HPLC Studies of Tissue Extracts-Mice (7 months old, CR:CFW strain, average weight $40 \mathrm{~g}$ ) were injected ip with a solution of the adenosine derivative (dissolved in 0.5 $\mathrm{mL}$ of $20 \%$ aqueous DMSO). After $30 \mathrm{~min}, 200 \mu \mathrm{L}$ of pentobarbital $(70 \mathrm{mg} / \mathrm{mL})$ were injected ip, and $500 \mu \mathrm{L}$ of blood was collected by cardiac puncture (right auricle) into a syringe containing $50 \mu \mathrm{L}$ of EDTA $(5 \mathrm{mM})$ and frozen on dry ice. The brains were removed and placed on dry ice.

Tissue Preparation—Blood $(200 \mu \mathrm{L})$ was mixed with $600 \mu \mathrm{L}$ of acetonitrile at $4{ }^{\circ} \mathrm{C}$ and vortexed for $30 \mathrm{~s}$. After centrifuging on the microfuge for $2 \mathrm{~min}$, the supernatant was removed and evaporated under nitrogen, and the residue was redissolved in acetonitrile containing $0.1 \%$ trifluoroacetic acid (HPLC solvent A, $60 \mu \mathrm{L}$ ). A chopped whole brain was ground (tissue grinder or dounce homogenizer) with $500 \mu \mathrm{L}$ of acetonitrile, vortex-mixed in a glass tube, and centrifuged $10 \mathrm{~min}$ at no. 5 speed $(500 \times \mathrm{G})$ on a clinical centrifuge. The supernatant was removed and evaporated under nitrogen. The residue was redissolved in 50 $\mu \mathrm{L}$ of HPLC solvent $\mathrm{A}$.

HPLC Conditions-Plasma and brain extracts were analyzed for the appropriate adenosine derivative (compared to standard) by reversed-phase HPLC. A C-18 column (Rainin, $0.4 \times 25 \mathrm{~cm}, 5 \mu, 300$ - $\AA$ pore size, $2.3 \mathrm{~mL} / \mathrm{min}$ ) was used, with a mobile phase consisting of mixtures of solvent A and water containing $0.1 \%$ trifluoroacetic acid, using a gradient of 5-10\% (20 min), followed by 10-15\% (2 min), and 15-20\% (18 min). Detection was by $\mathrm{UV}$ absorption at $254 \mathrm{~nm}$. The retention time of compound $\mathbf{1 2 b}$ was $30 \mathrm{~min}$.

Locomotor Activity-Individual adult male mice of the NIH (Swiss) strain between 5 and 6 weeks of age weighing at least $25 \mathrm{~g}$ were studied in a Digiscan activity monitor (Omnitech Electronics Inc., Columbus, $\mathrm{OH}$ ) with computerized data analysis (ILAM software). ${ }^{2,3}$ Different animals were used for each experiment. Adenosine and xanthine analogs were dissolved in a 20:80 v/v mixture of Alkamuls EL-620 (formerly Emulphor, Rhône-Poulenc, Cranbury, NJ) and phosphate buffered saline and injected ip in a volume of $5 \mathrm{~mL}$ per $\mathrm{kg}$ body weight. Where appropriate, the antagonist was injected 5 min prior to injection of the agonist. Animals were placed in the cage immediately after the final injection, and monitoring was begun after $5 \mathrm{~min}$. Total distance traveled was used as a measure of 
locomotor activity. Activity was monitored for up to $90 \mathrm{~min}$, with data collected in 10-min intervals. Control values for vehicle-injected animals were determined for each experiment.

Lipolysis Assay-The following protocol was used for determination of adenosine agonist effects on in vivo lipolysis. Sprague-Dawley rats (200-250 g) were fasted overnight. A blood sample was taken from the tail vein $10 \mathrm{~s}$ before the subcutaneous injection of the drug (adenosine agonist or simultaneous combination of agonist and antagonist) in vehicle (DMSO). The volume injected was $0.1 \mathrm{~mL} / 100 \mathrm{~g}$ body weight. Additional blood samples were taken from the tail vein at 30,60, and 90 min postinjection and were kept on ice and centrifuged (14000g) within $30 \mathrm{~min}$. A perchloric acid extract (3\%) of plasma was neutralized with a solution containing $3 \mathrm{M}$ potassium hydroxide, $0.5 \mathrm{M} 3$ morpholinopropanesulfonic acid, and 0.1 M EDTA and then assayed enzymatically for glycerol as described. ${ }^{15}$ Each data point was the average for three animals.

Electrophysiology-Sprague-Dawley rats (200-300 g) and gerbils were sacrificed by decapitation under deep anesthesia with pentobarbital. Hippocampal slices were prepared as previously described. ${ }^{16}$ Extracellular recordings of field excitatory postsynaptic potentials (fEPSPs) were recorded in the stratum radiatum of area CA1 in response to stimulation of the combined Schaffer collateral and commissural afferents. Slices were superfused continuously for 30-40 min with artificial cerebrospinal fluid (ACSF), ${ }^{16}$ and drugs were tested by addition to the ACSF. The amplitudes of the fEPSPs in control and drug-treated slices were measured on-line with a computer (PC) and plotted over the time course of each experiment. The $\mathrm{IC}_{50}$ value was the concentration of an adenosine agonist that inhibited the fEPSP by $50 \%$.

Temperature Depression-An adenosine analogue was administered to SpragueDawley male (250 g) rats, by injection either ip (dissolved in saline) or icv (dissolved in ACSF). For icv administration, a 22-gauge cannula was implanted stereotaxically under pentobarbital anesthesia. Drug was administered 3-7 days post cannula implant in $10 \mu \mathrm{L}$ of solution over a 10-min period. Rectal temperature was recorded at 30-min intervals for as long as $3 \mathrm{~h}$.

\section{Acknowledgments}

K.A.J., M.M., and K.S.L. wish to acknowledge the generous financial support of Cortex Pharmaceuticals, Inc., Irvine, CA, and NSF Grant No. RNS-8901154 to K.S.L.

\section{References}

1. Snyder SH, Katims JS, Annau Z, Bruns RF, Daly JW. Adenosine receptors and the actions of the methylxanthines. Proc Natl Acad Sci USA. 1981; 78:3260-3264. [PubMed: 6265942]

2. Nikodijevic O, Daly JW, Jacobson KA. Characterization of the locomotor depression produced by an $A_{2}$-selective adenosine agonist. FEBS Lett. 1990; 261:67-70. [PubMed: 2307237]

3. Nikodijevic O, Sarges R, Daly JW, Jacobson KA. Characterization of $A_{1}$ - and $A_{2}$-adenosine receptor mediated components in locomotor depression elicited by adenosine agonists. J Pharm Exp Ther. 1991; 259:286-294.

4. Durcan MJ, Morgan PF. NECA-induced hypomotility in mice: Evidence for a predominantly central site of action. Pharmacol Biochem Behav. 1989; 32:487-490. [PubMed: 2727008]

5. Barraco RA, Bryant SD. Depression of locomotor activity following bilateral injections of adenosine analogs into the striatum of mice. Med Sci Res. 1987; 15:421-422.

6. Daly JW, Padgett W, Shamim MT, Butts Lamb P, Waters J. 1, 3-Dialkyl-8-(psulfophenyl)xanthines: potent water-soluble antagonists for $\mathrm{A}_{1}-\mathrm{A}_{2}$-adenosine receptors. J Med Chem. 1985; 28:487-492. [PubMed: 2984420] 
7. Baumgold J, Nikodijevic O, Jacobson KA. Penetration of adenosine antagonists into mouse brain as determined by ex vivo binding. Biochem Pharmacol. 1992; 43:889-894. [PubMed: 1540242]

8. Evans MC, Swan JH, Meldrum BS. An adenosine analogue, 2-chloroadenosine, protects against long term development of ischaemic cell loss in the rat hippocampus. Neurosci Lett. 1987; 83:28792. [PubMed: 3441311]

9. von Lubitz DKJE, Marangos PJ. Cerebral ischemia in gerbils: Postischemic administration of cyclohexyl adenosine and 8-sulfophenyltheophylline. J Mol Neurosci. 1990; 2:53-59. [PubMed: 2257200]

10. Seale T, Abla KA, Shamim MT, Carney JM, Daly JW. 3,7-Dimethyl-1-propargylxanthine: a potent and selective in vivo antagonist of adenosine analogs. Life Sci. 1988; 43:1671-1684. [PubMed: 3193854]

11. Bruns RF. Role of adenosine in energy supply/demand balance. Nucleosides Nucleotides. 1991; 10:931-943.

12. Jarvis MF, Schutz R, Hutchinson AJ, Do E, Sills MA, Williams M. [ $\left.{ }^{3} \mathrm{H}\right] \mathrm{CGS} 21680$ anA 2 selective adenosine receptor agonist directly labels $\mathrm{A}_{2}$ receptors in rat brain tissue. J Pharmacol Exp Ther. 1989; 251:888-893. [PubMed: 2600819]

13. Jacobson KA, Kirk KL, Padgett WL, Daly JW. Functionalized congeners of adenosine: preparation of analogues with high affinity for Al-adenosine receptors. J Med Chem. 1985; 28:1341-1345. [PubMed: 2993623]

14. Cheng YC, Prusoff WH. Relationship between the inhibition constant $\left(\mathrm{K}_{\mathrm{i}}\right)$ and the concentration of inhibitor which causes 50 percent inhibition $\left(\mathrm{IC}_{50}\right)$ of an enzyme reaction. Biochem Pharmacol. 1973; 22:3099-3108. [PubMed: 4202581]

15. Eggstein, M.; Kuhlman, E. Triglycerides and glycerol. In: Bermeyer, HU., editor. Methods of Enzymatic Analysis. Academic Press; New York: 1974. p. 1825-1831.

16. Lee, K.; Oliver, M.; Schottler, F.; Lynch, G. Electron microscopic studies of brain slices: the effects of high-frequency stimulation on dentritic ultrastructure. In: Kerkut, GA.; Wheal, HV., editors. Electrophysiology of Isolated Mammalian CNS Preparations. Academic Press; London: 1981. p. 189-211.

17. Van Galen PJM, IJzerman AP, Soudijn W. Adenosine derivatives with $\mathrm{N}^{6}$-alkyl, -alkylamine, or alkyladenosine substituents as probes for the $A_{1}$ adenosine receptor. FEES Lett. 1987; 223:197201.

18. Reddington M, Lee K, Schubert P. An A1-adenosine receptor characterized by $\left[{ }^{3} \mathrm{H}\right]$ cyclohexyladenosine binding mediates the depression of evoked potentials in the rat hippocampal slice preparation. Neurosci Lett. 1982; 28:275-279. [PubMed: 6281693]

19. Vannucci SJ, Klim CM, Martin LF, LaNoue KF. A 1 -Adenosine receptor mediated inhibition of adipocyte adenylate cyclase and lipolysis in Zucker rats. Am J Physiol. 1989; 257:E871-E878. [PubMed: 2558574]

20. Clemo HF, Bourassa A, Linden J, Belardinelli L. Antagonism of the effects of adenosine and hypoxia on atrioventricular conduction time by two novel alkylxanthines: correlation with binding to adenosine $A_{1}$ receptors. J Pharmacol Exp Ther. 1987; 242:478-484. [PubMed: 3612546]

21. Ticho SR, Radulovacki M. Role of adenosine in sleep and temperature regulation in the preoptic area of rats. Pharmacol Biochem Behav. 1991; 40:33-40. [PubMed: 1780343]

22. Lee TF, Li DJ, Jacobson KA, Wang LCH. Improvement of cold tolerance by selective A1 adenosine receptor antagonists in rats. Pharmacol Biochem Behav. 1990; 37:107-112. [PubMed: 2263650]

23. Busto R, Dietrich WD, Globus MY, Ginsberg MD. Postischemic moderate hypothermia inhibits CA1 hippocampal ischemic neuronal injury. Neurosci Lett. 1989; 101:299-304. [PubMed: 2771174]

24. Brodie MS, Lee K, Fredholm BB, Stahle L, Dunwiddie TV. Central versus peripheral mediation of responses to adenosine receptor agonists: evidence against a central mode of action. Brain Res. 1987; 415:323-330. [PubMed: 3038272]

25. Van Galen PJM, Stiles GL, Michaels G, Jacobson KA. Adenosine $A_{1}$ and $A_{2}$ receptors: Structurefunction relationships. Med Res Rev. 1992; 12:423-471. [PubMed: 1513184] 
26. Evoniuk G, von Borstel RW, Wurtman RJ. Antagonism of the cardiovascular effects of adenosine by caffeine or 8- (p-sulphophenyl)-theophylline. J Pharmacol Exp Ther. 1987; 2:428-432. [PubMed: 3806407]

27. Dunwiddie T, Fredholm B. Adenosine receptors mediating inhibitory electrophysiological responses in rat hippocampus are different from receptors mediating cyclic AMP accumulation. Naunyn-Schmiedeberg's Arch Pharmacol. 1984; 326:294-301.

28. Thornton JD, Liu GS, Olsson RA, Downey JM. Intravenous pretreatment with $\mathrm{A}_{1}$-selective adenosine analogues protects the heart against infarction. Circulation. 1992; 86:659-665. [PubMed: 1735160]

29. Ukena D, Olsson RA, Daly JW. Definition of subclasses of adenosine receptors associated with adenylate cyclase: interaction of adenosine analogs with inhibitory A1 receptors and stimulatory A2 receptors. Can J Physiol Pharmacol. 1987; 66:365-376. [PubMed: 3580959]

30. Sturm K, Muschaweck R, Hropot M. 5-Sulfamoylorthanilic acids, a sulfonamide series with salidiuretic activity. J Med Chem. 1983; 26:1174-1187. [PubMed: 6876086]

31. Hansch, C.; Leo, A. Substituent constants for correlation analysis in chemistry and biology. WileyInterscience; New York: 1979.

32. Bridges AJ, Bruns RF, Heffner TG. Central nervous system actions of adenosine agonists and antagonists. Annu Rep Med Chem. 1988; 23:39-48.

33. Dunwiddie T, Worth T, Olsson R. Adenosine analogs mediating depressant effects on synaptic transmission in rat hippocampus: Structure-activity relationships for the $\mathrm{N}^{6}$-subregion. NaunynSchmiedberg's Arch Pharmacol. 1986; 334:77-85. 


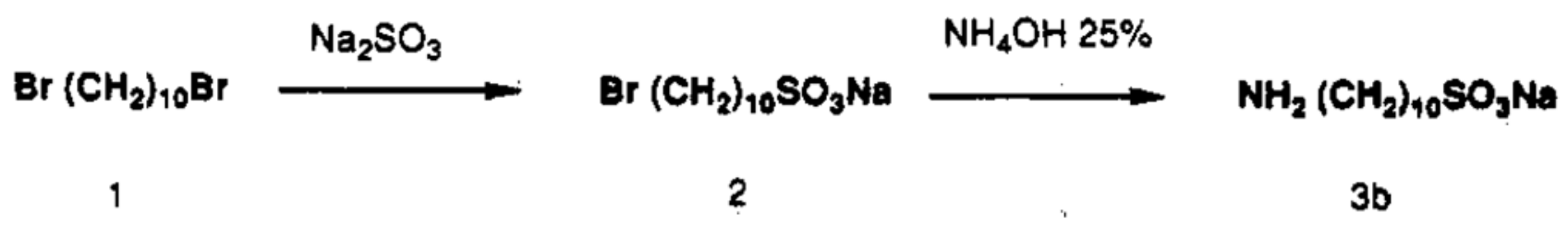

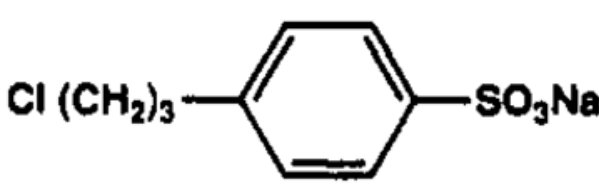

4

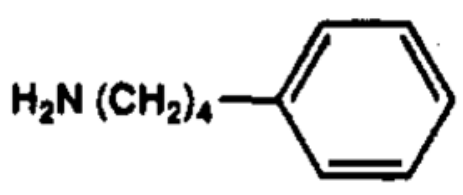

5
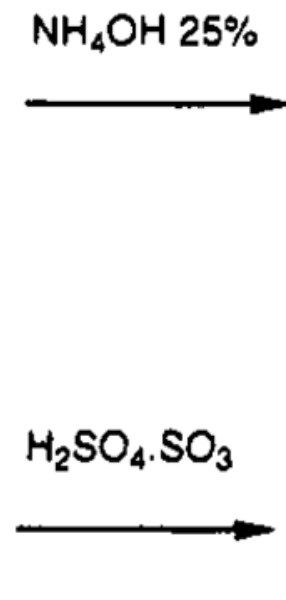

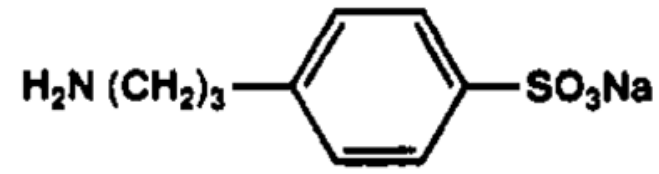

$6 b$

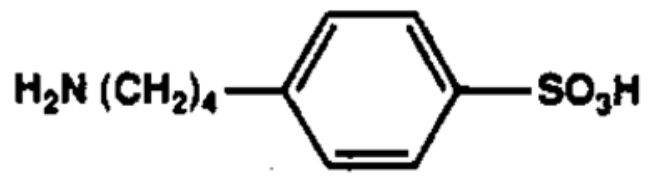

Figure 1.

Synthesis of sulfoaralkylamine and sulfoalkylamine intermediates. 


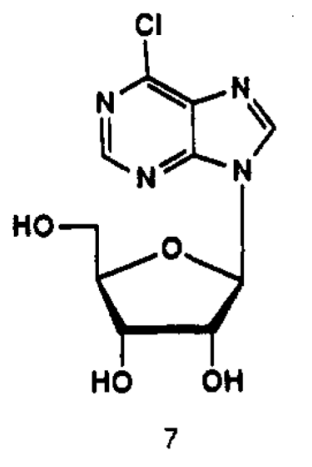

$+\quad \mathrm{H}_{2} \mathrm{~N} \cdot \mathrm{Z}-\mathrm{SO}_{3} \mathrm{X}$

$$
\begin{aligned}
3 a-b Z & =\left(\mathrm{CH}_{2}\right)_{n} \\
6 \text { a.c } Z & =\left(\mathrm{CH}_{2}\right)_{n} \\
X & =\mathrm{Na} \text { or } \mathrm{H}
\end{aligned} \quad \begin{aligned}
& \mathrm{n}=2,10 \\
& \mathrm{n}=0,3,4
\end{aligned}
$$

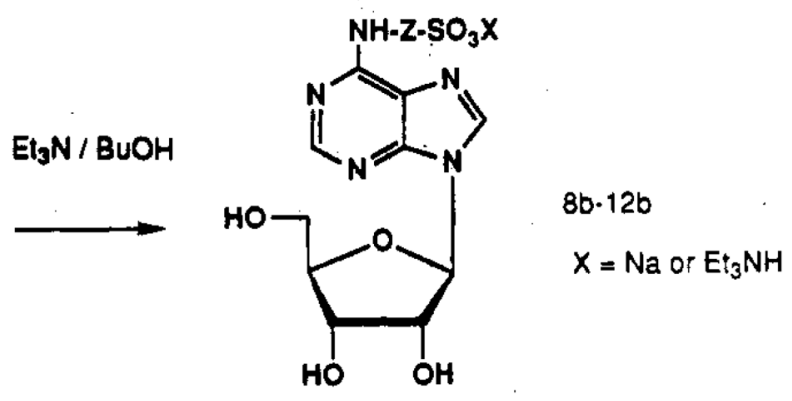

Figure 2.

Synthesis of $N^{6}$-(sulfoaralkyl)- and $N^{6}$-(sulfoalkyl)-adenosine analogs. 


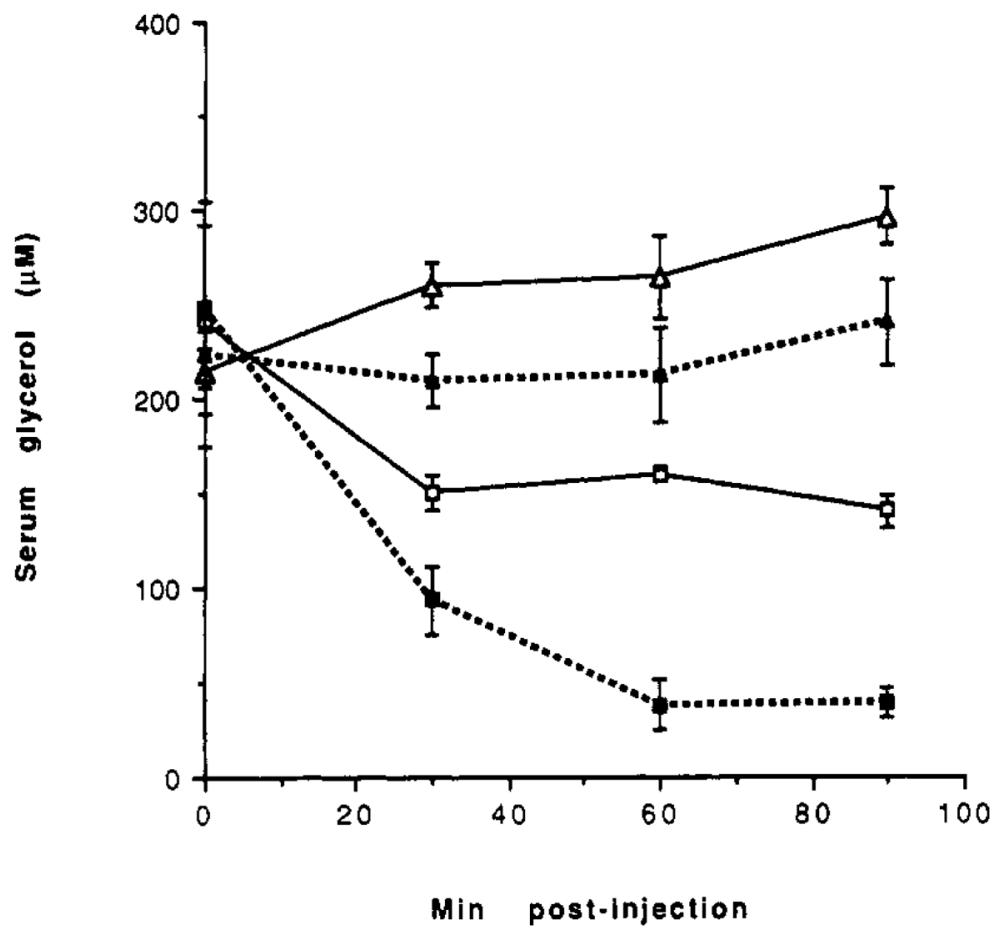

Figure 3.

Time course for the effects of sulfoadenosine derivatives on lipolytic activity in rats $(n=3$ for each point). Serum glycerol levels were measured enzymatically. ${ }^{15} \mathrm{Key}$ : animals injected with $10 \mathrm{~b}$ at $0.1 \mathrm{mg} / \mathrm{kg}$ sc (open symbols) or $\mathbf{1 2 b}$ at $1.0 \mathrm{mg} / \mathrm{kg}$ (closed symbols) for adenosine agonist alone (squares) or combination of agonist and BW1433, $4.0 \mathrm{mg} / \mathrm{kg} \mathrm{sc}$ (triangles). BW1433 alone raised serum glycerol levels by a small amount, from $296 \pm 20$ $\mu \mathrm{M}$ before injection to $326 \pm 15 \mu \mathrm{M}$ at 60 min postinjection. 

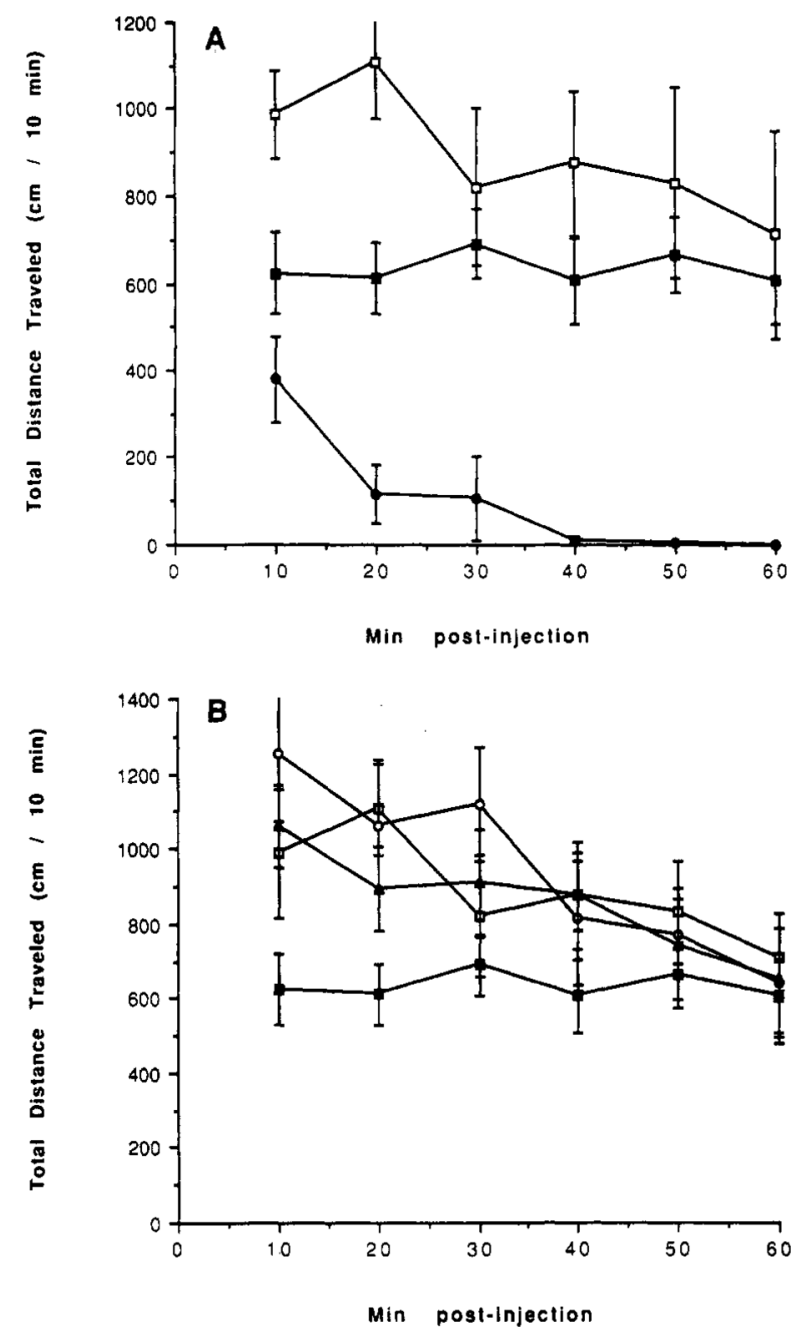

Figure 4.

(A) Effects of $N^{6}$-(4-sulfophenyl)adenosine, $\mathbf{1 0 b}$, on locomotor activity in mice. ${ }^{3}$ Key: vehicle-injected animals (open squares), $\mathbf{1 0 b}$ at $0.3 \mathrm{mg} / \mathrm{kg}$ ip (closed squares), $\mathbf{1 0 b}$ at 1.0 $\mathrm{mg} / \mathrm{kg}$ ip (circles); $n=7-25$. $P$ values for control vs $0.3 \mathrm{mg} / \mathrm{kg} \mathbf{1 0 b}$ were $<0.01$ at $10 \mathrm{~min}$ and $<0.001$ at $20 \mathrm{~min}$. (B) Reversal by the adenosine antagonist BW1433 of the locomotor depression elicited by a $0.3 \mathrm{mg} / \mathrm{kg}$ dose of compound 10b. Key: vehicle-injected animals (open squares), 10b at $0.3 \mathrm{mg} / \mathrm{kg}$ ip (closed squares), 10b + BW1433, $4.0 \mathrm{mg} / \mathrm{kg}$ ip (triangles), BW1433 alone (circles); $n=10-25$. 

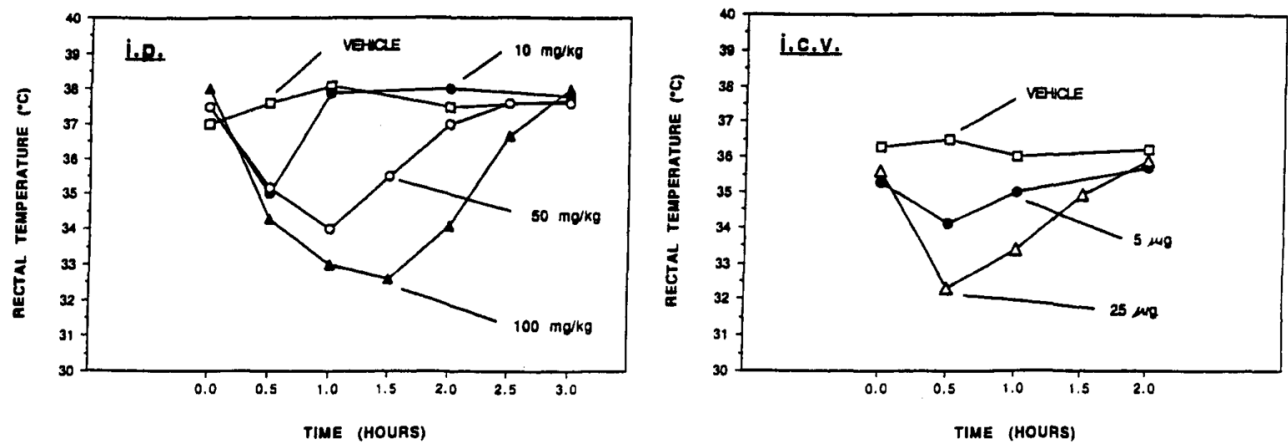

Figure 5.

Effects of compound 11b on body temperature in rats: (a) by ip administration at the dose indicated or (b) by icv administration in a cannulated animal. 


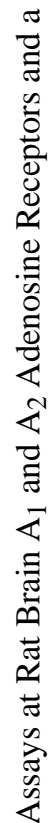

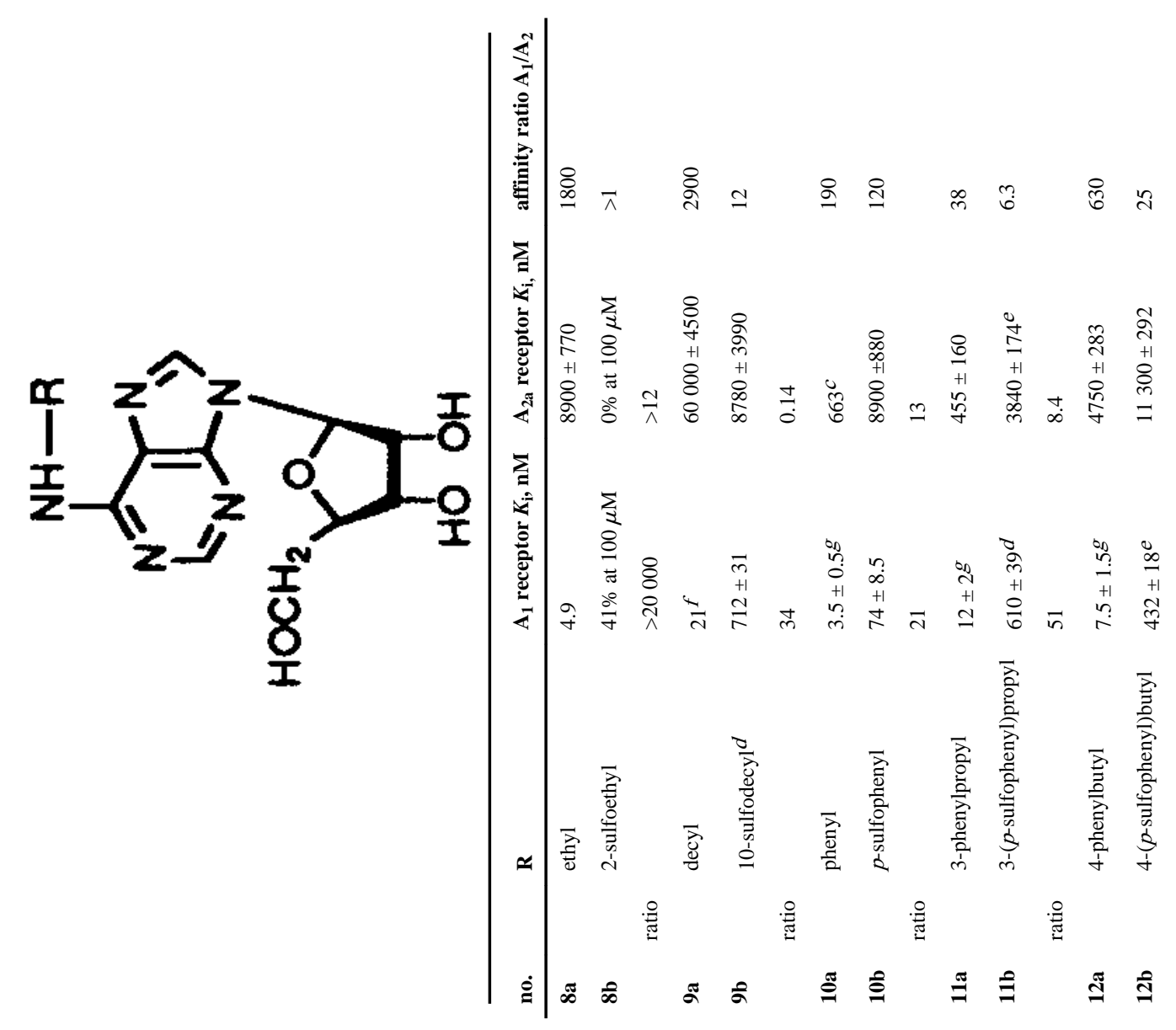






JMed Chem. Author manuscript; available in PMC 2012 August 16. 


\section{Table II}

Potency of Adenosine Analogs as Inhibitors of Synaptic Potentials in the Hippocampal Formation ${ }^{18}$ (synaptic responses (fEPSPs) were recorded in the CA1 region of in vivo hippocampal slices, in rat brain, unless noted)

\begin{tabular}{lll}
\hline compound $^{\boldsymbol{a}}$ & $\mathbf{I C}_{\mathbf{5 0}, \mathbf{n M}}$ & $\boldsymbol{K}_{\mathbf{i}}$ at $\mathbf{A}_{\mathbf{1}}$ receptors, $\mathbf{n M}^{\boldsymbol{c}}$ \\
\hline CPA & 10 & 0.59 \\
ADAC & 17 & 0.85 \\
CHA & 50 & 1.3 \\
$\mathbf{1 0 b}$ & 74 & 74 \\
& $63 b$ & \\
$R$-PIA & 86 & 1.2 \\
$N$-Ac-ADAC & 105 & 9.3 \\
NECA & 160 & 10.3 \\
2-CADO & 620 & 9.3 \\
11b & 1700 & 610 \\
$S$-PIA & 5400 & 1820 \\
CGS21680 & 18000 & 2600 \\
adenosine & 26000 & \\
\hline
\end{tabular}

${ }^{a}$ For key to abbreviations, see ref 25 .

$b_{\text {In gerbil brain. }}$

$c_{\text {Data from refs } 13,25,29 .}$ 